\title{
JESUS OF NAZARETH'S TRIAL IN THE UNCENSORED TALMUD
}

\author{
David Instone-Brewer
}

\begin{abstract}
Summary
The Munich Talmud manuscript of b.San.43a preserves passages censored out of the printed editions, including the controversial trial of 'Yeshu Notzri'. Chronological analysis of the layers in this tradition suggests that the oldest words are: 'On the Eve of Passover they hung Jesus of Nazareth for sorcery and leading Israel astray.' This paper argues that other words were added to this tradition in order to overcome three difficulties: a trial date during a festival; the unbiblical method of execution; and the charge of 'sorcery'.
\end{abstract}

\section{The Origin of Censorship}

The Munich Talmud is the earliest full manuscript Talmud, penned in 1343. ${ }^{1}$ A few manuscripts of the Talmud have survived from before the invention of printing as well as many fragments, and these are particularly important because they contain material censored out of the printed editions, most of which concerned Jesus.

Daniel Bomberg, a Christian printer in Venice in the early 1500 s, spent most of his professional life and family fortune printing 230 major Jewish works, including the Jerusalem Talmud and the massive editions of the Babylonian Talmud and the Mikraot Gedolot (the Rabbinic Bible) with their surrounding commentaries. He worked mainly with Felice da Prato, an Augustinian friar who had converted from Judaism. They followed the page layout invented by the Soncino family for printing the tractate Berakhot in 1483, which has a central

1 H. L. Strack and G. Stemberger. Introduction to the Talmud and Midrash (Edinburgh: T\&T Clark, 1991): 227-30. 
Talmud passage with commentaries arranged around the edge of the page. They applied this system to all the tractates and completed the first full printed Talmud in $1520 .^{2}$ This page layout was so useful that it became standard, and exactly the same layout is still reproduced today for printing the Talmud.

Bomberg's printing of the Talmud ensured its survival because a few years later, in 1553, Pope Julius III ordered the burning of all Talmuds, ${ }^{3}$ but multiple printed copies had already spread everywhere. One was sold in London in 1628 for $£ 26$, then went missing, and was rediscovered in 1991 in Sion College's basement. ${ }^{4}$ Without Bomberg's printed edition, the Munich Talmud might be the only full copy of the Talmud which survived. His printing is essentially identical to the normal nineteenth-century edition usually known as 'Vilna' though some of these tractates were printed in up to four separate and subtly different editions. ${ }^{5}$

Censorship helped Bomberg get papal permission to print the work. In 1518 he petitioned the Venetian Senate to renew his printer's licence, and took the opportunity to buy the exclusive rights to print the Talmud, which had to be officially endorsed by Pope Leo X. ${ }^{6}$ The censorship was meant to remove all disparaging passages about Jesus, which included any passages concerning Jesus or Mary and most passages which might involve disputes with Christians.

There is some uncertainty about the origin of Bomberg's censorship. Possibly Bomberg inherited censorship which was already present in the manuscripts he used. His edition is based on various manuscripts which were compared to produce his text. However, for the few tractates already printed by the Soncino family in the late 1400 s, he

2 Marvin J. Heller, 'Earliest Printings of the Talmud' in Printing the Talmud: From Bomberg to Schottenstein, Sharon Liberman Mintz and Gabriel M. Goldstein (New York: Yeshiva University Museum, 2005): 61-78, esp. 73; online at http:// www.printingthetalmud.org/essays.html.

3 Richard Gottheil and William Popper, 'Confiscation of Hebrew Books' in The Jewish Encyclopedia, ed. Isidore Singer, Cyrus Adler, (12 vols; New York: Funk and Wagnalls, 1901-1906).

4 http://www.untoldlondon.org.uk/community/jewish/article/priceless-talmud-display -lambeth-palace [accessed 16 June 2011].

5 Avraham Rosenthal, The Talmud Editions of Daniel Bomberg: A Comprehensive Collection of All Tractates of the Four Editions by Bomberg, Venice 1520-1549 (Microfiche collection, Jerusalem: IDC, 1997). He discusses the differences in 'Daniel Bomberg and His Talmud editions' in Gli Ebrei e Venezia, XIV-XVIII (Proceedings of the international conference in Venice, 1987): 375-416.

6 Heller, 'Earliest Printings', 73. 
was accused of simply copying their edition without comparing manuscripts. This copying is particularly blatant in Sukkah where he left gaps on pages where there are diagrams in the Soncino edition. Apparently he did not have time to commission his own woodcuts before the printing deadline. ${ }^{7}$ Some of the manuscripts used by Soncino (including Sanhedrin) had been censored by the Spanish authorities after the Disputation of Tortosa $(1414)^{8}$ so Bomberg may have inherited this censorship, and he may have used other similarly censored manuscripts.

However, self-censorship is more likely because Bomberg's missing and altered passages are not identical to anyone else's. For example, the text in b.Git.57a, which says Jesus was punished with boiling faeces in hell, is uncensored in surviving manuscripts which have this section (Vatican 130, 140; Munich 95) but censored in two different ways in the early printed editions: Soncino simply removes the name 'Jesus' while Bomberg substituted 'the sinners of Israel'. ${ }^{9}$ Similarly the passage about Jesus' trial (considered in this paper) is uncensored in surviving manuscripts which include this section (Herzog 1, Firenze II.1:8-9, Karlsruhe 2, Munich 95) but it is censored differently in the early printed editions: the Soncino edition (sometimes called Barco, after the town where it was printed) erased Jesus' name; but Bomberg's edition omits the whole passage. ${ }^{10}$

Censorship was therefore imposed on Jews in the Fifteenth Century, but Bomberg and the Soncino family felt it was necessary to continue this practice, and Jewish councils later ratified this decision. ${ }^{11}$

7 Heller, 'Earliest Printings', 74.

8 'Tortosa, Disputation of', Encyclopaedia Judaica (Jerusalem: Encyclopaedia Judaica, 1972): XV 1270-71.

9 Peter Schäfer, Jesus in the Talmud (Princeton, N.J: Princeton University Press, 2007): 141, where 'Vilna' is the Bomberg edition.

10 Schäfer, Jesus in the Talmud, 139.

11 Paul L. B. Drach, De l'harmonie entre l'Eglise et la synagogue, ou, Perpétuité et catholicité de la religion chrétienne (Paris: P. Mellier, 1844): I 168 cites a rabbinic encyclical from Poland in 1631: 'we enjoin you, under the pain of excommunication major, to print nothing in future editions, whether of Mishna or of the Gemara, which relates whether for good or evil to the acts of Jesus the Nazarene, and to substitute instead a circle like this ' $\mathrm{O}$ ', which will warn the Rabbis and schoolmasters to teach the young these passages only viva voce. By means of this precaution the savants amongst the Nazarenes will have no further pretext to attack us on this subject.' $<$ http:// www.archive.org/stream/delharmonieentr00unkngoog\#page/n206/mode/2up> accessed 12 Oct.2011. 


\section{Censored Passages}

The Munich Talmud is therefore the only uncensored copy of the whole Talmud, though even this is censored in some respects. The name of Jesus and other words are frequently very faint, as though someone has attempted to erase them. In the passage about Jesus' trial, the two occurrences of the name 'Yeshu ha-Notzri' have been partially erased in this way, as well as parts of the following passage about the names of his disciples. However, the original Hebrew is still visible, and it has been reconstructed by examination of the manuscript. These reconstructions are usefully collected in an appendix by Herford. ${ }^{12}$

The censored passages are almost all late anti-Christian polemics. They have been collected and analysed by Herford and more recently in great detail by Schäfer. ${ }^{13}$ The name of Jesus does not always occur in censored passages. Some refer to 'Ben Stada' (ברן סטדא) or 'Ben Pandira' (בן פנדירא), but there is good evidence that these are pseudonyms for Jesus in such passages. In b.San.67a both these names are used for the same person who is described as 'hung on the Eve of Passover' - the same phrase which is used of Yeshu ha-Notzri in b.San.43a. Also, Tosephta refers to 'Yeshu ben Pandira' ( ישור בן), פנדירא), and it has a story about a follower of him, Jacob of Kephar Sekhania who met Eliezer b. Hyrcanus (late First or early Second Century) in Sepphoris near Nazareth (t.Hull. 2:23). Tosephta's version of this story says that he taught Eliezer a saying of the minim-a term which refers to heretics, including Christians. The saying itself is found at b.AZ.17a, where the Munich Talmud attributes it to 'Yeshu haNotzri' (ישו הנוצרי).

When later Talmudic rabbis debated these names, they concluded that the same person was called both 'ben Stada' and 'ben Pandira' because one was the name of his mother's husband and the other was her lover, so they concluded that Yeshu was illegitimate. One rabbi thought that 'Stada' was the name of his mother, because it is similar to sotah (סטרָה, 'unfaithful'), but others pointed out that her name was actually Miriam-i.e. Mary (b.Shab.104b). ${ }^{14}$

12 R. Travers Herford, Christianity in Talmud and Midrash (London: Williams \& Norgate, 1903; New York, KTAV, 1975): 406.

13 Herford, Christianity; Schäfer, Jesus in the Talmud.

14 This discussion is only in uncensored Talmuds. 
Some scholars have concluded that these multiple names represent a more than one individual, who have become confused, ${ }^{15}$ though Schäfer argues that the alternative names may be intentionally enigmatic or offensive. ${ }^{16}$ The prehistory of these traditions is probably impossible to trace but, as Schäfer points out, the congruence of the date of execution - the day before Passover - is too striking to ignore, and the differences between the details in the Talmud and Gospel could be due to deliberate misrepresentation by later Jews. ${ }^{17}$

The passage about Jesus' trial at b.San.43a is unique among these censored traditions because part of it may date back to the time of Jesus (as argued below). Most scholars dismiss its historical value, arguing that details like the herald for forty days show it is hopelessly inaccurate. Any similarity to the Gospel account is explained as dependence on Christian traditions - probably on the Gospel of John because this alone states that Jesus was killed on Passover Eve. ${ }^{18}$ However, this dismissal is perhaps an overreaction against earlier uncritical readings. ${ }^{19}$ Others, with a more nuanced approach, have recognise that an earlier core has been heavily edited ${ }^{20}$ so unhistorical details do not require a rejection of the complete tradition.

15 John P. Meier. A Marginal Jew Volume 1: Rethinking the Historical Jesus (The Anchor Bible Reference Library; New York: Doubleday, 1991): 96 n. 44 refers to Johann Maier. Jesus von Nazareth in der talmudischen Überlieferung (Erträge der Forschung; Darmstadt: Wissenschaftliche Buchgesellschaft, 1978): 237, and others who conclude that Ben Stada was certainly a separate individual, and possibly Ben Pandira, and that their traditions became linked with the Jesus traditions at a very late stage, and calls this 'a common opinion'.

16 Schäfer, Jesus in the Talmud, 16-18.

17 Schäfer, Jesus in the Talmud, 12.

18 This is the general conclusion of Paul Winter, On the Trial of Jesus (Studia Judaica, Forschungen zur Wissenschaft des Judentums 1; Berlin: Walter de Gruyter, 1961): 201-202; Simon Légasse, The Trial of Jesus (London: SCM, 1997): 4-6; Raymond E. Brown, The Death of the Messiah (London: Geoffrey Chapman, 1994): 2:376-77; Walter Grundmann, 'The Decision of the Supreme Court to Put Jesus to Death (John 11:47-57) in Its Context: Tradition and Redaction in the Gospel of John' in Jesus and the Politics of His Day, ed. Ernst Bammel and C. F. D. Moule (Cambridge: CUP, 1984): 300.

19 This is exemplified in Joseph Klausner, Jesus of Nazareth: His Life, Times, and Teaching (London: Allen \& Unwin, 1925); see the historical survey in David R. Catchpole, The Trial of Jesus: A Study in the Gospels and Jewish Historiography from 1770 to the Present Day (Studia Post-biblica 43; Leiden: Brill, 1971): 1-71.

20 See Ernst Bammel, 'The Titulus' in The Trial of Jesus: Cambridge Studies in Honour of C. F. D. Moule, ed. Bammel (Studies in Biblical Theology SS 13; Naperville, IL: Alec R Allenson, Inc, 1970): 353-64: esp. 360-61; William Horbury, 'The Benediction of the "minim" and Early Jewish-Christian Controversy', JTS NS 33 (1982): 19-61 esp. 55; Catchpole, The Trial of Jesus, 4-9. 
This paper will argue that the tradition, as preserved in Talmud, has -been edited, but the common pattern of editing in rabbinic traditions is to expand the text while leaving the original words unaltered. So the original words may have survived because rabbinic editors were reluctant to change words they had inherited, though they were willing to add words which would help the reader to understand the meaning.

One of the consistent findings in the TRENT project (which aims to identify all rabbinic material which can be shown to originate before $\mathrm{AD} 70^{21}$ ) is that rabbinic editors were generally conservative with traditions from the past. They rarely changed wording, even when they did not understand the vocabulary, and they tended to add words to the end of an inherited tradition, though they sometimes interrupted a tradition by inserting explanatory phrases. Identifying the earliest core of a tradition is often difficult because it depends on occasional attributions and coherence with other datable sources, so conclusions are often conjectural. However, in the case of this tradition, more than one source has survived and these can help us to identify the early core of the tradition.

\section{The Censored Text at b.San.43a}

The reference ' $b$. San.43a' is artificial, because this refers to the folio page numbers of Bomberg's edition and subsequent editions which use the same page layout, but all these editions omit this passage. If this passage had been included in the Bomberg edition, it would have occurred at the very bottom of the folio side $43 \mathrm{a}$, and this is where some modern versions insert it. In the actual manuscript of the Munich Talmud, this passage occurs on page 679 of the facsimile:



This image shows that at various points there has been an attempt to erase the text. The following reconstruction is based on the facsimile, with some standardised spelling, and on Herford who consulted the

21 David Instone-Brewer, Traditions of the Rabbis from the Era of the New Testament (vols. 1-2A; Grand Rapids, MI: Eerdmans, 2004-). 
manuscript itself, and dotted underlining represents the partially erased text.

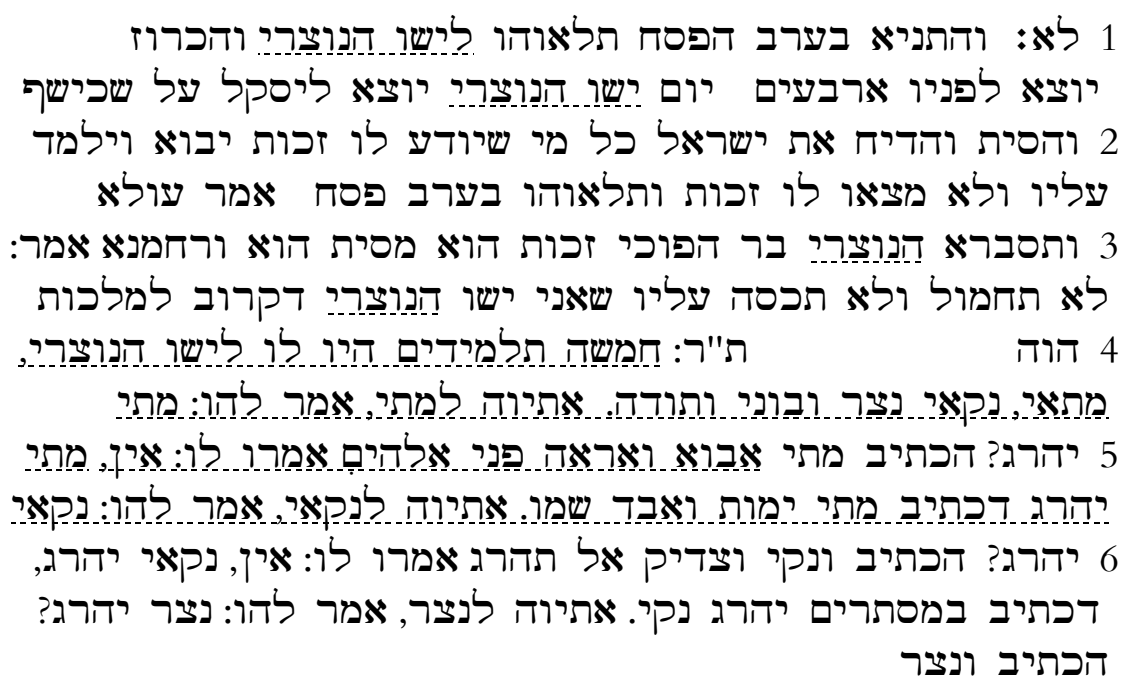

The tradition investigated in this paper includes most of the first two lines in this image. In the translation below, the words in bold are those that this paper will conclude were the original core of this tradition, and the ones in grey are those which have been partly erased in the Munich manuscript:

It was taught: On the Eve of Passover they hung Yeshu the Notzri. And the herald went out before him for forty days [saying]: 'Y eshu the Notzri will go out to be stoned for sorcery and misleading and enticing Israel [to idolatry]. Any who knows [anything] in his defence must come and declare concerning him.' But no one came to his defence so they hung him on the Eve of Passover.

Other manuscripts which have this tradition contain a few variants. The Florence manuscript has 'on the Eve of Shabbat and Eve of Passover' and only the Munich manuscript includes ' ha-Notzri'.

This passage is followed by a later comment by Ulla bar Ishmael (about AD 300) and another censored passage that lists and discusses the supposed names of Jesus' disciples. These sections have no evidence of originating before the Third Century, and will not be considered further in this paper:

Ulla said: 'And would it be expected that the Notzri revolutionary had a defence? He was a "misleader",' and the Merciful said (Deut. 13:9) 'You shall not spare and shall not shield him.' But it was not so for Yeshu the Notzri for he was close to the government. 
Our rabbis taught: Yeshu the Notzri had five disciples-Matai, Nekai, Netzer, Buni, and Todah.

They brought Matai [before the judges]. He said to them: 'Will Matai be killed? It is written (Ps. 42:2) "When [matai] shall (I) come and appear before God." They said to him: 'Yes, Matai will be killed as it is written (Ps. 41:5) "When [matai] shall (he) die and his name perish.""

They brought Nekai. He said to them: 'Will Nekai be killed? It is written (Exod 23:7) "The innocent [naki] and the righteous you shall not slay.", They said to him: 'Yes, Nekai will be killed as it is written (Ps. 10:8) "In secret places he slays the innocent [naki]."'

They brought Netzer. He said to them: 'Will Netzer be killed? It is written (Isa 11:1) "A branch [netzer] ...

[Here the image and transcription end. The passage continues:]

... shall spring up from his roots." They said to him: "Yes, Netzer will be killed as it is written (Isa 14:19) "You are cast forth out of your grave like an abominable branch [netzer].",

They brought Buni. He said to them: 'Will Buni be killed? It is written (Exod 4:22) "My son [beni], my firstborn, Israel." They said to him: 'Yes, Buni will be killed as it is written (Exod 4:23) "Behold, I slay your son [bincha] your firstborn.",

They brought Todah. He said to them: "Will Todah be killed? It is written (Ps. 100:1) "A Psalm for thanksgiving [todah]." They said to him: 'Yes, Todah will be killed as it is written (Ps. 50:23) "Whoever sacrifices thanksgiving [todah] honours me.",

\section{Dating the Edited Tradition}

The Talmud is an edited and severely abbreviated record of discussions by rabbis over a period of 300 years, starting in about AD 200 when the document they were discussing was edited. They were discussing the Mishnah which was itself a record of previous discussions covering about 200 years concerning how to live out the commands of Torah in practice. This means that both documents contain older and later material which has been skilfully compiled and edited. The process of unravelling the layers of editing is still in its infancy. Most commentaries on the Talmud originate from a precritical era when such questions did not arise. The principles employed in this paper are commonplace among rabbinic scholars, but there is no standard commentary on the Talmud to which one can turn for an analysis to help with dating individual units. ${ }^{22}$

22 Many commentaries have been written on the Talmud, but there are no modern commentaries except on some individual sections - see Strack, Introduction, 234-41. The nearest attempts are Jacob Neusner, The Talmud of Babylonia: An Academic Commentary (22 vols; Atlanta, GA: Scholars Press, 1994-); and Hersh Goldwurm, 
The Talmud progresses through Mishnah, discussing one small unit at a time, much like a modern Bible commentary. It frequently appears to contain irrelevant digressions, though most of these can be related back to the discussion in hand. Often, as with this tradition in b.San.43a, an older tradition is cited because it throws light on the subject. If the cited tradition is one which has not been preserved in Mishnah, they often cite it in full, and when it is closely linked with another tradition or traditions which were transmitted as a single unit, then the whole unit is included. This practice tends to introduce seemingly irrelevant material which sometimes creates discussions which digress from the original subject. However, this practice has the beneficial side effect of preserving some traditions which would otherwise be lost.

In b.San.43a, the tradition about Jesus' trial relates to the preceding discussion, but the tradition about the trial of Jesus' disciples has no relevance to any nearby discussion. Therefore it is likely that these two traditions were transmitted together as a single unit and inserted together at this point.

The discussion at this point in the Talmud relates to Mishnah Sanhedrin 6:1 which concerned how a trial should end and how a herald should proclaim the verdict. The discussion is commenced by Abaye, a Babylonian Amora functioning about AD 320-350. His comment is followed by a separate comment from an anonymous rabbi who introduced the older tradition about Jesus' trial. This tradition is then commented on by R. Ulla bar Ishmael (about AD 290-320), after which the editors have recorded the tradition about executing Jesus' disciples. This is followed immediately with two comments by R. Joshua b. Levi (about AD 220-250), first about a sacrifice of thanksgiving (relating to the end of the tradition about Jesus' disciple Todah), and a second about a sacrifice of burnt offering and confession. This second comment leads into the discussion about the next unit of Mishnah, Sanhedrin 6:2, which concerns confession before execution, though this Mishnah unit is not quoted till after his contribution.

Talmud Bavli-Schottenstein Edition (Artscroll Series; 1st edn; New York: Mesorah Publications, 1992). The commentary in the former consists of introductory paragraphs and in-line explanations for difficult phrases, and in the commentary in the latter is an abridgement of classical rabbinic commentaries. The former inserts the censored text from another translation without comment, and the latter omits it. 
So, in outline, this section of the Talmud consists of:

1. Quotation of m.San. 6:1

(edited c. AD 200)

2. Discussing m.San. 6:1 by Abaye (in Babylon c. AD 320-350)

3. Discussing $m$.San. $6: 1$ by an anonymous rabbi

4. Quotation of Jesus' trial tradition

5. Discussing Jesus' trial tradition by Ulla (in Babylon c. AD 290-320)

6. Quotation of Jesus' disciples' trial (Mattai to Todah)

7. Discussing Todah's trial by Joshua b. Levi (Palestine c. AD 220-250)

8. Discussing m.San. 6:2 by Joshua b. Levi(in Palestine c. AD 220-250)

9. Quotation of m.San. 6:2

10. Discussing $m$.San. $6: 2$ by various rabbis ...

(edited c. AD 200)

This final text developed slowly during the Third to Sixth Centuries. The history of development can often be inferred from internal factors, and for this text there are enough indicators to allow us to infer the development in considerable detail.

Quotations of Mishnah normally occur immediately before the start of a discussion of them, so the quotation at (9) is slightly misplaced-it should be before (8). However, the addition of Mishnah quotations was one of the latest stages in the development of Talmud, so its placement here may be either a simple error (because the editor did not realise Joshua's second saying related to the next Mishnah unit) or (more likely) because the editor did not want to break up Joshua's two sayings.

The dates given for Ulla and Abaye represent the dates of the 'generations' into which rabbis are categorised. We do not know dates of the active careers of individual rabbis, so we cannot define the dates of these rabbis any more accurately. This means that they may well have overlapped so they could take part in a discussion together at around AD 320. However, it is not possible that Joshua could have been there at that time, so this section includes and merges at least two separate discussions.

The two traditions about the trial of Jesus and his disciples, (4) and (6), have been separated by Ulla's comment (5). This suggests that Ulla's generation inherited a text which already included these two traditions, and that he no longer regarded them as a single unit. His generation therefore felt free to insert his comment after the first one where it was more relevant. Ulla's comment shows that he had profound problems with this tradition, but he did not propose any amendment of it, which suggests that the wording was already too fixed to allow any alteration. 
The anonymous rabbi who introduced the traditions about Jesus and his disciples must have been earlier than Ulla by one or more generations. He was also earlier than or contemporary with Joshua $b$. Levi, because Joshua's first comment is based on the end of the tradition about the trial of Jesus' disciples. The simplest solution is that this anonymous rabbi was debating with Joshua, which means he was in Palestine at the start of the Third Century. This is very soon after the editing of the Mishnah which they were discussing, so it is unlikely that this anonymous rabbi could have been from an earlier generation.

The discussion at m.San. 6:1 refers to a herald who walks before the condemned person on their way to execution, calling for any last minute evidence for the defence. This caused the anonymous rabbi to introduce this tradition about Jesus' trial because it too referred to a herald. However, these two references to a herald are very different and somewhat contradictory. In the Mishnah the herald's announcement follows the trial and occurs only on one day, during the condemned man's journey to the place of execution. In the tradition about Jesus' trial, the herald's announcement is made for forty consecutive days preceding the trial. No rabbis proposed a correction to either tradition to solve this contradiction, which implies that they were both being treated as having comparable standing in terms of age and authority.

Although these two traditions about the trials of Jesus and his disciples were transmitted as a unit, they were originally independent units, because they both have a separate introductory formula: 'It is taught' and 'Our rabbis taught'. Both of these formulae are normally used for traditions originating with Tannaim-i.e. rabbis of Mishnaic times before AD 200 - though the presence of such a formula is not an infallible marker of an early origin. However in this case, it is likely that these formulae are accurate because this helps to explain why the rabbis regarded this Jesus tradition as if it had comparable authority to Mishnah.

Therefore the historical layers which have been merged in this unit of Talmud are:

1. Mishnah (though actual quotations were added later) (ed. c. AD 200)

2. Traditions of the trials of Jesus and his disciples (ed. c. AD 200)

3. Discussion: Joshua b. Levi with another (in Palestine c. AD 220-250)

4. Discussion between Ulla and Abaye

(in Babylon c. AD 320)

These traditions of the trials which were cited in the early Third Century were already considered to be authoritative, so they must have 
become fixed by at least the end of the Second Century. The form of the tradition at this time already included the reference to the herald, which the discussion below will conclude is one of the later additions to this tradition. This would mean that the form of this tradition at the end of the Second Century was already edited and expanded. We will now attempt to find the earliest core of this tradition.

\section{Other Sources for the Tradition of Jesus' Trial}

The tradition about Jesus' trial, as preserved in Talmud, includes internal indicators which suggest that it has been edited. In order to identify the earliest tradition, we first look for other places where the tradition has been preserved, and then examine the internal coherence of the tradition itself. The tradition of Jesus' trial has been partially preserved in four other sources:

1. Another censored passage at b.San.67a includes the words 'on the eve of Passover they hung', followed by other names used for Jesus, 'Ben Stada' and 'Ben Pandira'.

2. and 3. The words 'for sorcery and enticing Israel' occur at Sanhedrin $107 \mathrm{~b}$ with a parallel at Sotah $47 \mathrm{a}$.

4. Outside the Talmud, two charges are recorded by Justin Martyr who said that as a result of Jesus' miracles, the Jews 'dared to call him a

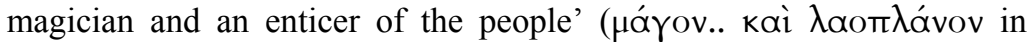
Dial. 69). Stanton pointed out that these two charges also occur together in the Third Century Acts of Thomas 96 where Thomas is charged with them, though clearly as a proxy for Jesus. They also occur in Josephus' Testimonium but this is widely believed to be a Christian addition of unknown date. ${ }^{23}$

There is some confusion over the charges. Only two charges are recorded in b.San.107b and in Justin, though b.San.43a and some versions of b.San.107b insert 'and misleading' between the two. It is likely that $b$. San $107 \mathrm{~b}$ originally had just two charges, because a scribe would be more inclined to add a missing charge in b.San.107b to harmonise with b.San.43a than to delete a charge. It will also be suggested below that there was a good reason for adding the charge of 'misleading'. The earlier record by Justin helps to confirm that

23 Graham Stanton, 'Jesus of Nazareth: A Magician and False Prophet Who Deceived God's People?' in Jesus of Nazareth: Lord and Christ: Essays on the Historical Jesus and New Testament Christology, ed. Joel B. Green and Max Turner (Grand Rapids, MI: Eerdmans/, Carlisle: Paternoster Press, 1994): 164-80, esp. 169-70. 
originally there were only two charges. He only needed to cite the charge of 'sorcery' to make his point, so one would expect him to quote the only the first and third charges, which would be a strange decision if he had known that the intervening charge existed.

It is not immediately clear whether Justin's term $\lambda$ aom $\lambda$ ávos is equivalent to "misleader" (mesit, מִִִית) or "enticer" (maddiyah, מַדִדירה). These English translations convey something of the etymological meaning of these terms, but they are arguably synonymous in Deuteronomy 13:5-13 (Eng. 6-14- סות is in Eng. v. 6 and נדח in vv. $5,10,13)$. However, the Mishnah manages to find a distinction which is continued into Talmud and became the legal definition of these words in Jewish law. The terms 'enticer' in this passage is used only for the crime of leading a whole town into idolatry (Deut. 13:13), so the Mishnah concluded that a 'misleader' was someone who merely leads a single person into idolatry (m.San. 7:10). The term $\lambda \alpha о \pi \lambda \alpha$ ávos is (etymologically) a 'people deceiver', and although it does not occur in the LXX, it is used by Josephus concerning prophets who lead the nation astray. ${ }^{24}$ Josephus is therefore using it as an equivalent of an 'enticer' who leads a large number into idolatry, rather than a 'misleader' who leads only one astray.

Günter Mark has argued that mesit was central to the purpose of this tradition in later centuries. When Ulla equates it to someone who is 'close to the government' he was indicating a new meaning for this term as not only someone who leads an individual astray, but a Jew who apostasises and sides with non-Jewish rulers. At the time of Ulla, Christianity was becoming institutionalised, and Mark regards this as the halakhic response to a wave of new apostates. ${ }^{25}$

Horbury noted the significant fact that all these sources agree about the order of the two earlier charges (i.e. 'sorcery' followed by 'enticing'), whereas this is opposite to the order found in all legal discussions - in Deuteronomy, Mishnah and the relatively independent

24 Josephus, Ant. 8.8.5 [225] retells and elaborates the events of $1 \mathrm{Kgs}$ 13:1-3: 'Jeroboam ... built an altar before the heifer, and undertook to be high priest himself. ... A prophet, whose name was Jadon... said thus: 'God foretells that there shall be a certain man of the family of David, Josiah by name, who shall slay upon thee those false priests that shall live at that time, and upon thee shall burn the bones of those deceivers of the people, those impostors and wicked wretches.'

25 Günter Mark, 'Jesus "was close to the authorities": The Historical Background of a Talmudic Pericope', JTS 60 (2009): 437-66. 
account in Tosephta. ${ }^{26}$ One would expect that the common occurrence of these charges as a pair in a particular order would be reflected in the tradition of Jesus' trial, and yet none of the versions of this tradition referred to the charges in this order. This suggests that this pair of charges in these traditions about Jesus did not originate in halakhic discussions, but they had a separate and authoritative source.

The fact that various sources have survived with parts of the tradition about Jesus' trial suggests that this tradition was widely known and well preserved. However, the origin of the tradition remains difficult to identify. The Talmudic sources are difficult to date because although some named rabbis are involved, they are citing older traditions and, as often occurs, the origin of these traditions is not identified. Justin is writing in about AD 150, and he appears to be citing something which is common knowledge because he makes no effort to verify it for his Jewish opponent whom he is addressing.

We therefore have confirmation from three rabbinic sources and from one Christian source for the words: 'On the eve of Passover they hung Yeshu for sorcery and enticing Israel'. The fact that these words form a coherent tradition by themselves makes it possible that this was the historic core from which the rest has resulted by the addition of explanatory comments. The fact that the other words cannot be paralleled elsewhere is not an indication by itself that they originated later than this core tradition, but there are internal criteria which do suggest that this was the case.

\section{Problems Implicit in the Expanded Tradition}

The final form of Jesus' trial tradition has four difficulties or inconsistencies which have been introduced by the explanatory additions. These internal problems will be explored first, before looking for possible reasons for making these additions.

The first internal problem concerns the method of execution. The tradition says a herald proclaimed that Jesus was due to be stoned for his crimes, and yet it also says that he was 'hung'. The obvious solution is that he was first stoned and then his corpse was hung as a public warning. However, the hanging receives far more emphasis in

26 Horbury, 'The Benediction of the "minim"”, 55; Deut. 13:6-11, 12-18 [7-12, 13-19] then 18:10; m.San. 7:10 then 7:11; t.San. 11:5. 
this tradition than his punishment by stoning - the tradition opens with the fact that he was hung on a specific date, and this is repeated at the end of the tradition, and the only reference to stoning occurs on the lips of the herald as something which should happen. This is not an insurmountable problem, but it suggests that more than one hand has composed this tradition, which has resulted in a confusing emphasis.

The second problem is the issue of the forty days during which the herald called for witnesses to the defence before the trial. The only Mishnaic law about a herald refers to someone who precedes the condemned person while being led from the trial to the place of execution (m.San. 6:1). It is this problem which caused the anonymous rabbi to introduce the tradition of Jesus' trial into the debate. Referring to the Mishnah, he pointed out that 'This implies, [the herald goes out] only immediately before [the execution], but not previous thereto'. He then cited the tradition about Jesus' trial to contradict this. In the Talmudic discussion, this issue is left unresolved.

This mention of a herald who goes out before the trial introduces a third problem: he is said to go out for forty days. There is no authority anywhere for this number of days relating to a trial. The closest is a reference to thirty days in m.San. 3:8. This says that a judge may allow a delay of thirty days for finding evidence in support of someone, though this procedure was not mandatory or even normal, and we know of no case where a court actively helped the defence in this way. This problem provoked Ulla's question, which pointed out that even if it was customary, it would not apply to someone on such a seriously dangerous charge. Someone answered Ulla that Jesus must have had friends in high places.

The fourth problem involves the list of charges, because the second one is implied in the third. As seen above, in Mishnaic and Talmudic times, the term 'misleader' referred to someone who leads a single person into idolatry whereas an 'enticer' leads a whole town or more into idolatry. This means that any 'enticer' is, by definition, also a 'misleader'. Both are listed as capital offences (m.San. 7:4), but no one would be charged with both, because this would be like charging someone with both genocide and murder. One crime implies the other and there would be no purpose listing the lesser crime unless it added to the penalty, or unless this was a list of possible charges before the trial. However, in this case we have a list of charges which Jesus was found guilty of, all of which carried the death penalty. There would 
therefore be no point in adding that the person who led the whole of Israel into idolatry also led an individual into idolatry-i.e. the charge of 'enticing' makes the additional charge of 'misleading' entirely redundant.

\section{Problems Implicit in the Core Tradition}

None of these internal inconsistencies existed in the core tradition: 'On the Eve of Passover they hung Yeshu for sorcery and enticing Israel'. However, this does not mean that this core tradition was without problems. The wording of this tradition would cause three difficult problems for Jews, especially in the Second Century and beyond, though these problems may not have existed in the early First Century.

The first problem was the date of the trial and execution. The Passover Eve refers to the whole day preceding the Passover mealmuch like Christmas Eve refers to a whole day. Although Passover Eve was not officially part of the Passover festival, it was important as the day when leaven was searched for and cleared out of each home. This grew in importance especially after the destruction of the temple in AD 70 , when the sacrifice of a lamb became impossible, though it was already important in temple times. A timetable was instituted by which leaven had to be found by noon on Passover Eve, and a signal was given at the temple when this search should end (m.Pes. 1:5). The School of Shammai (which effectively disappeared after AD 70) agreed with the School of Hillel that the whole day should be devoted to searching for leaven so no other work should occur (m.Pes. 1:1; 4:5).

This meant, in effect, that the whole day of Passover Eve was devoted to sacred tasks and it was certainly not the right time for a trial or an execution. We have no evidence that this date would be illegal for a trial, but it is certainly not a date which would be chosen by any court interested in observing Jewish customs. In the First Century it would be an embarrassment that Jewish leaders had chosen this date, though it was not a great difficulty. Different branches of Judaism had different regulations, and some chose to continue working normally on Sabbath Eve (m.Pes. 4:1). However, in the Second Century when the ceremony of finding leaven had become more important and Judaism was united around rabbinic law, this would be a much greater problem. 
The second problem in this core tradition is the suggestion that the execution was by hanging rather than by being stoned, as prescribed by Torah and Mishnah. Torah was very clear that stoning was the punishment for 'enticing' (Deut. 13:6-10) though it did not prescribe a death penalty for 'sorcery' (Exod. 22:18; Deut. 18:10). However, in a second-century debate, the rabbis concluded that sorcery was punished by stoning, partly because the sorceress is listed alongside the woman guilty of bestiality which was punishable by stoning (see the debate at b.San.67a). Mishnah makes a tidy list of crimes punished by stoning, which included 'sorcery', 'enticing' and 'misleading' (m.San. 7:4).

The term 'hang' could refer to execution by hanging from the neck, execution by crucifixion, or the hanging of a corpse after another form of execution. Without any reference to another form of execution, the assumption in the First or Second Century would be that 'hang' refers to crucifixion. This is what R. Meir assumed when he expounded Deuteronomy 21:23 (about hanging as an indication of God's curse) by telling a parable about crucifixion. So someone reading the core tradition without any mention of stoning would conclude that Jesus was executed by crucifixion.

This conclusion would create problems in the Second Century when Judaism was attempting to follow a uniform rabbinic halakha. They sometimes reinterpreted history to imply that the rabbinic halakha had already been followed by everyone before AD 70. They even said that Sadducean priests had been forced by the Pharisees to obey this halakha. ${ }^{27}$ They would therefore like to believe that executions were carried out in accordance with rabbinic halakha. However, Jews living in the First Century would not be embarrassed by a tradition which said they had used a Roman form of execution, because they had a more realistic understanding of what was possible, and they knew the Romans were in charge of capital punishment.

The third problem was the most important because it threatened to draw many more people to revere Jesus. The charge of 'sorcery'

27 For example, they thought the High Priest on the Day of Atonement obeyed the Pharisees: 'they forced [the High Priest] to swear [to obey the Sages]' (t.Kipp. 1:8) cf. b.Yom.19b: 'the father [of a priest who disobeyed the Sages] met him [and] said to him: My son, although we follow the Sadducees we fear the Pharisees'; m.Yom. 1:6: 'If [the High Priest] was a sage, he expounds [the Scriptures], and if not, disciples of sages expound for him; if he was used to reading [Scriptures], he read, and if not, they read for him.' 
implies that Jesus had real power, because rabbinic law did not prescribe death for magic tricks carried out by illusionists.

Second-century rabbis made a very clear distinction between real and imaginary magic, and they were quite sophisticated at recognising illusions. For example Rab Abba b. Aibu reported: 'I myself saw an Arabian traveller take a sword and cut up a camel; then he rang a bell and the camel arose'. R. Hiyya saw through it: 'Was any blood or dung left behind? If not, it was merely an illusion.'(b.San.67b). R. Joshua (start of Second Century) had a saying about how someone charged with sorcery and someone charged with illusion might look identical to the uneducated: 'Two people are gathering cucumbers: one gatherer is innocent, and the other gatherer is guilty. ${ }^{28}$ This type of saying was presumably well known because it is similar to the collection of sayings at Luke 17:34-36 which share the common formula: there are two people doing something, one person doing it will die and the other person doing it will live.

In the Second Century many Jews believed that Jesus had learned magic in Egypt. This is already believed by Celsus who debated with Origen in the late Second Century (Origen, Contra Celsum, i. 28), and it later caused the traditions of Jesus to become linked with traditions about magic in Talmud (b.San.107b/b.Sot.47a). Among the amulets and incantation bowls surviving from the Second and Third Centuries, some contain the name of Jesus along with mainly Jewish names such as the angels named in 1 Enoch. ${ }^{29}$ This had even spread to Gentiles, who made spells such as 'I conjure you by the god of the Hebrews,

28 In the Kaufman MS, this is changed to 'one gatherer [qal part.] is innocent and the other causing to gather [piel part.] is guilty'. This brings it into line with the story which developed later about spells for harvesting cucumbers (b. San.68a).

29 See Gideon Bohak, Ancient Jewish Magic: A History (Cambridge: Cambridge University Press, 2008): 278; John Michael Greer, The New Encyclopedia of the Occult (St. Paul, MN : Llewellyn, 2003): 248. Markham J. Geller, 'Jesus' Theurgic Powers: Parallels in the Talmud and Incantation Bowls', JJS 28 (1977): 141-55. We are not sure how incantation bowls were used, but they are frequently found buried upside down under houses, especially thresholds, as though they could trap evil spirits which tried to enter the house from below. Similarly, Jesus is named in Jewish exorcism rites - see Hans Dieter Betz, The Greek Magical Papyri in Translation V.1: Including the Demotic Spells (2nd edn; Chicago: University of Chicago Press, 1992): 62, PGM IV, 1230-62 'Hail God of Abraham; hail God of Isaac; hail God of Jacob; Jesus Chrestos' - this is a Jewish exorcism because the patient is later kept safe by hanging phylacteries round his neck. 
Jesus'. ${ }^{30}$ The synchronistic nature of these inscriptions makes it possible that Gentiles liked to use Jewish holy names, but the presence of so many Jewish names and even rabbinic formulae ${ }^{31}$ makes it certain that Jews were also among those who used them.

In the First Century, the verdict that Jesus' miracles were sorcery would be regarded as a condemnation of his ministry. But in the latter part of the First Century these amulets became popular in Palestine ${ }^{32}$ and Jews became enamoured with such spells. The eclectic lists of names suggest that people were no longer concerned with the source of healing power, but with power itself. In this context, the fact that Jesus was convicted of 'sorcery' became a dangerous enticement in itself because it confirmed that Jesus had power to heal.

\section{Explanatory Additions to Solve These Problems}

It was not possible to solve these problems by changing the words of the original tradition because they were too well known. We can see how widespread this tradition was from the fact that it has survived in three separate places in rabbinic sources and one in a Christian source. In any case, it was not normal practice for rabbinic editors to change the wording of texts they had received. Even when the older texts used vocabulary which was archaic and even when they disagreed with its meaning, they preserved the older wording. Sometimes they added explanations for older words or to 'correct' the meaning of the tradition, and sometimes their explanations reveal that they were not sure what the original words meant. In these situations it is significant that they nevertheless preserved the older version, even though it was a possible source of confusion for later generations.

The normal method of editing was to add explanatory glosses, preferably after the end of a tradition, but also within a tradition when this was more helpful. A useful example is the list of things one may or may not wear on a Sabbath in m.Shab. 6:1-4, the core of which almost certainly originated in Temple times because the ruling required

30 PGM IV, 3020 in Betz, Greek Magical Papyri, 96.

31 See Geller, Jesus' Theurgic, 150-51.

32 Amulets and bowls had already been used for centuries, but they spread to Palestine and Syria - see Haim Gitle, 'Four Magical and Christian Amulets', Liber Annuиs 40 (1990): 365-74. 
making a sin offering. This list grew with time, becoming interspersed and followed by later glosses. The second half of this passage reads:

3. A woman may not go out:

with a needle [which is] pierced, nor with a ring which has a seal, nor a snail, nor an ankle chain, nor a bottle of spikenard perfume.

But if she goes out, she is liable for a sin offering.

[The above are] the words of R. Meir, but the Sages exempt the ankle chain and the bottle of spikenard perfume.

4. A man may not go out:

not with a dagger, nor with a bow, nor with a shield, nor with a spear, nor with a lance.

And if he goes out he is liable for a sin offering.

R. Eliezer [b. Hyrcanus] says: They are ornaments for him ...

And the Sages say: They are nothing but shameful, as it is said: 'And they shall beat their swords into ploughshares ...' [Isa. 2:4]

A garter is pure and they may go out with it on Sabbath.

An ankle chain is impure and they may not go out with it on Sabbath.

Most additions in halakhic discussions are made at the end of a complete tradition, like the comments of Eliezer and the sages at the end. Even though these included comments about the ankle chain mentioned in (3), they wait till the end of this tradition. But sometimes it is more efficient to interpose an addition in the middle of a tradition, such as the comment that the ankle chains and perfume bottles had been added by Meir. Meir's addition is interesting because it appears to be an explanatory gloss of an unusual word in this old tradition - the strange prohibition of a 'snail' ( changing this word, Meir added a possible explanation based on the similar sounding 'perfume-charm' (kokhelet, כוֹכְלֶת), and because this also was an unusual word he added 'bottle of spikenard perfume'. Unfortunately Meir's first word was subsequently miscopied as 'anklechain' (kobelet, כוֹבֶלֶ). This illustrates the reluctance of later rabbis to change what they have inherited but their willingness to help the reader by adding explanations. ${ }^{33}$ It is also a salutary warning that scribal accidents can happen.

33 This tradition is analysed in more detail in David Instone-Brewer, Feasts and Sabbaths: Passover and Atonement (Traditions of the Rabbis from the Era of the New Testament 2A; Grand Rapids, MI: Eerdmans, 2011). 
All of the problems with the core tradition which were identified above can be solved by adding explanations within the tradition and following it. There are three likely additions:

On the Eve of Passover they hung Yeshu the Notzri.

1. And the herald went out before him for forty days [saying]: 'Yeshu the Notzri will go out to be stoned

for sorcery

2. and misleading and enticing Israel [to idolatry].

3. Any who knows [anything] in his defence must come and declare concerning him.' But no one came to his defence so they hung him on the Eve of Passover.

These explanatory glosses may have been added at one time, or they may have been added at separate times by more than one editor. The first gloss and third gloss are linked and were perhaps added at the same time. However, the tradition makes sense as a complete unit without the third gloss, so it is possible that this was added later. We will consider each possible gloss in turn.

The first gloss solves two of the three problems identified above: the unusual trial date and the non-Jewish method of execution. The latter is solved simply by adding a mention of stoning as the prescribed execution. This means that the ambiguous term 'hung' can now refer to hanging a corpse in public as a warning to others.

Hanging up a corpse is discussed at b.San.45b. This concludes that a corpse is hung up if the person was stoned for blasphemy or idolatrywhich would presumably include those 'enticing' others to idolatry. Eliezer ben Hyrcanus (AD 80-120) disputed this by reasoning that if you hang people in this way, you should do it for everyone who is stoned. Eliezer had Scripture on his side because the context of Deuteronomy 21:23 concerns the stoning of a stubborn and rebellious son which is one of the lesser categories of crime deserving death. Later rabbis argued that a 'rebellious son' was not hung because he was not yet 'a man'. They also argued that blasphemers and idolaters were hung because they had cursed God, so it was right that they should be seen to be cursed by God (Deut. 21:23; b.San.45b-46a).

The fact that this discussion took place during Eliezer's generation demonstrates that hanging idolaters was not the normal practice at the end of the First Century. It is difficult to imagine that idolaters who had been stoned in the early First Century could be hung up in public view. Although it is likely that mobs occasionally stoned someone (as at John 
8:2-7 and Acts 7:58), this was outlawed by Rome (John 18:31). Therefore hanging up the corpse in public would attract the attention of soldiers who would be compelled to investigate such a public flouting of the law.

In the Second Century it was still difficult to carry out stoning and hanging, but it was possible to rewrite history and assume that this had been possible in the past. They wanted to show that Judaism in temple times followed rabbinic halakha to help inspire those in the present. And it was especially important to show that this high profile case had been dealt with correctly, according to the law of Moses.

Therefore, by the mere addition of the herald's announcement that Jesus was supposed to be stoned, the whole meaning of this tradition was changed. This addition did not subvert the meaning of the passage, as far as the rabbinic editors were concerned. They would have regarded it as helping the reader understand the meaning of the ambiguous term 'hung' so that they would know it referred to the hanging of a corpse, and not to the hanging of crucifixion.

The problem concerning the trial date was more difficult to solve. The date of the trial was clearly on a holy day when work was forbidden by many branches of Judaism before AD 70 and by all Jews after AD 70. For later editors, this was not a suitable date for a trial, so they concluded that this date must have been forced on them by problems inherent in the trial. The addition said that a herald had gone out for forty days to give notice of the trial. The anonymous rabbi who introduced this tradition into the discussion was confused about this, because m.San. 6:1 said the herald should go out after the trial and only on the day the trial ends.

As suggested above, the forty days might relate to the ruling at m.San. 3:8 that a judge could allow up to thirty days for a defendant to find evidence, though this was not normal. This gloss therefore implies that the court was especially lenient in the case of Jesus, because it allowed more than thirty days. This leniency had to end at forty days because the Passover holiday was starting. Perhaps the public nature of this crime meant that justice had to be seen to be done before the holiday, in case the crowds start talking amongst themselves about the lack of law in the land. So the trial was held at the last possible legal moment. Although it was held on a day when rabbinic law said no work should be done, it was not held on a day when Mosaic law prohibited work. 
The addition of the single word 'misleading' creates problems while trying to solve others. The first problem is that this addition contradicts the other sources which record only two charges. But the bigger problem is that it creates an illogical set of charges. As seen above, 'enticing' refers to leading a town or country into idolatry, and 'misleading' refers to leading a single individual into idolatry, so the charge of 'misleading' one person is already implied by the charge of 'enticing' many people and the inclusion of both charges is illogical.

However, the presence of 'misleading' would make sense if it was added as an explanatory gloss rather than a separate charge. If a rabbinic editor regarded the charges as confusing or ambiguous, they could add a gloss like Meir did to explain the meaning of 'snail' in m.Shab. 6:3 (above). So perhaps 'misleading' was added to explain either the term 'enticing' or 'sorcery'. Normally an explanation would be added after the thing being explained, which suggests that it is inserted to help the reader understand the meaning of 'sorcery'.

Although this addition appears illogical at a later date, it is possible that this was not a problem in the Second Century. There was still some dispute in the Second Century about whether or not 'enticers' should be strangled (t.San. 11:5) and while this remained undecided, the inclusion of 'misleading' would explain why the execution was by stoning instead of strangling. This addition would not make sense before the addition of 'stoning' to this tradition, and it would start to appear illogical after the dispute about the mode of punishment had been settled-as it was in m.San. 7:4 perhaps near the end of the Second Century. Therefore, for some time during the Second Century, this addition helped the reader understand the tradition in the way the rabbinic editors understood it without creating additional problems.

It is proposed here that the addition of 'misleading' was made in order to help the reader realise that Jesus' sorcery was suspect. The charge of sorcery still implied that Jesus' miracles were genuine, because illusions did not warrant a death sentence, but the editor added a warning that this might be misleading.

\section{Dating the Earliest Core Tradition}

We concluded above that the traditions concerning the trials of Jesus and his disciples were added at or before the time of Joshua b. Levi (in 
Palestine about AD 220-250) who commented on the trial of the disciples. Joshua was from the first generation of rabbis commenting on the Mishnah, so the anonymous rabbi who introduced this tradition was unlikely to be earlier. The fact that this anonymous rabbi commented on the 'herald' of Jesus' trial implies that this tradition already contained this and presumably the other two additions as well.

It is difficult to know when the first addition was made, but the addition of 'misleading' was not known to Justin Martyr when he replied to Trypho in about AD 150. The other two charges however were already common knowledge, because Justin was able to cite them in the assurance that Trypho would know what he was referring to. These charges were therefore put together some time between the last year of Jesus and some decades before AD 150.

When looking for an origin of the core tradition, we need to explain the order of the charges. As detailed above, these two charges often occur together - in Deuteronomy, Mishnah, Tosephta and consequently in the Talmuds - but they are always discussed in the order of 'enticing' and then 'sorcery'. If this tradition originated as a comment based on scripture or halakha, the tradition would have followed this common order. The reverse order is found in all three sources which contain this tradition. This consistent reversal suggests that these charges were based on an original tradition concerning the trial.

The origin of this tradition cannot be traced to Christian sources. The Gospels say that Jesus was convicted of blasphemy by the Jews and of treason by the Romans (Matt. 26:65; Mark 14:64; Luke 23:2). For the gospel writers, these were the most significant charges because they confirmed what the Gospels themselves were trying to show: that Jesus was divine and a king. The gospels do not present blasphemy as a charge in the arrest warrant, but as a charge that was introduced during the trial (Mark 14:60-64; Matt. 26:63-65). The original charge in these gospel accounts concerned destroying the temple, which might have been an initial piece of evidence for the charge of enticing Israel into a new religion, but it is unlikely to make the reader infer that this was a charge brought against Jesus.

The charges of sorcery and leading Israel astray are recorded in the Gospels, but not as charges at his trial. The Synoptics record the charge that he cast out demons in the power of Satan (Mark 3:22; Matt. 12:24; Luke 11:15 and John records the accusation that he was 'leading Israel 
astray' (John 7:12). ${ }^{34}$ Therefore they are not absent from the Gospels, but they are merely two of several accusations, such as being a glutton and drunkard (Matt. 11:19; Luke 7:34-which warrant the death penalty, cf. Deut. 21:20), being of illegitimate birth (John 8:41) and blasphemy (Mark 2:7; Matt. 9:3; John 10:33). Therefore the Gospels do not contradict the charges of sorcery and enticing Israel, but neither can they be inferred from the Gospels. The Gospels are silent about the actual charges though the questioning at the start of the trial is consistent with a charge of 'enticing' Israel.

The origin of this tradition is also unlikely to be rabbinic or Pharisaic, even though it has been preserved in rabbinic literature. A rabbinic author or their Pharisee predecessors would cite the charges in the order found in Torah and rabbinic halakha. Also, rabbinic traditions and the major Pharisaic schools tried to dissuade people from working on Passover Eve, so they would not have invented a tradition which said that they decided to try Jesus on this date. Even if the tradition merely reflected the fact that the trial actually occurred on Passover Eve, the author of the tradition could have chosen to simply say that it happened 'before Passover' rather than emphasise the fact that it happened on a day contrary to their halakha.

Passover Eve was not kept as a holy day by all of the disparate factions which made up Judaism before AD 70. A tradition we have no reason to doubt says that those in Galilee avoided work all day, while those in Jericho allowed work all day, and those in Judaea allowed work only till noon (m.Pes. 4:5, 8). This may indicate that Sadducees or priests were more generally relaxed about Passover Eve than others, because a large number of priests lived in Jericho (b.Taan.27a) and it is likely that Judaea was influenced more by the Sadducees than by the Pharisees. This makes it likely that the original tradition about Jesus' trial came from a Sadducean source rather than a Pharisaic one, though the evidence on this point is not strong.

It is worth asking why this tradition was created. As a piece of fiction it conveyed little of interest to Jews. It was a matter of public knowledge that Jesus was executed, and the Jewish world would have liked to forget this rather than be reminded about this false prophet who caused so much trouble. And if someone had created this tradition to warn would-be messiahs, they would have omitted the embarrassing

34 For a fuller discussion see Stanton, 'Jesus', 170-80. 
facts about the date and mode of his execution, and they would probably have omitted the charge of sorcery.

Taking all these factors into consideration, the simplest solution is that this tradition originates from the actual charge sheet for the trial of Jesus. This would explain how it carried enough authority to ensure that all the sources maintain the reversed order of the charges, the unscriptural mode of execution and the impious trial date.

\section{Conclusions}

The traditions about the trials of Jesus and his disciples which were censored from b.San.43a were brought into the Talmudic discussions early in the Third Century and removed in the Fifteenth and Sixteenth Centuries. External evidence gives independent witness that the earliest core in this tradition was: 'On the Eve of Passover, they hung Jesus of Nazareth for sorcery and enticing Israel [to idolatry].' The rest of the tradition was added later as explanatory glosses to help the reader with problems which became particularly acute in the Second Century: the date of the trial; the method of execution; and the charge of 'sorcery'. These explanations had already been added by the end of the Second Century, because part of them is debated as an authoritative text by rabbis in the early Third Century.

The earliest development of this tradition cannot be traced with any certainty. The third charge was not present in about AD 150 when Justin Martyr cited two charges, though only the first was pertinent to his argument. He cited them as something which his Jewish opponent would be familiar with. The consistent order of the charges, which is opposite to that in Torah and rabbinic halakha, suggests they came from another authoritative source. The wording of the rest of the earliest core of this tradition is not what would have invented to help the case that Jesus was tried and executed according to Jewish law.

The least difficult explanation is that the earliest core of the censored tradition of Jesus' trial came from the time of Jesus. Succeeding generations felt they could not change it, despite difficulties presented by the wording. Instead, later editors added explanatory phrases during the latter half of the Second Century to help readers understand the correct meaning of this tradition, as they saw it. 